\title{
Development and Validation of UV-Derivative Spectroscopic and RP-HPLC Methods for the Determination of Amlodipine Besylate and Valsartan in Tablet Dosage form and Comparison of the Developed Methods by Student's T-Test
}

\author{
Usharani N, Divya K and Ashrtiha VVS \\ Maharajah's College of Pharmacy, Phool Baugh, Vizianagaram, Andhra Pradesh, INDIA.
}

\begin{abstract}
Introduction: Hypertension is directly responsible for $51 \%$ of all stroke deaths and $45 \%$ of all coronary heart diseases worldwide. Amlodipine besylate is a calcium channel blocker used as an anti-hypertensive agent. Valsartan is an angiotensin II receptor blocker used in the treatment of hypertension. Rationale: Fixed-dose combination products are becoming popular because of simplified dosage regimens, enhanced patient adherence and reduced costs. Therefore there is a need for analytical methods for consistent quality establishment throughout the shelf life of the product. Objective: To develop and validate UV derivative spectrophotometric and RP-HPLC methods for the simultaneous determination of Amlodipine besylate and Valsartan in tablet dosage form. To compare the developed methods by student's t-test for their suitability and sensitivity in routine quality control. Methods: For the simultaneous estimation of Amlodipine besylate and Valsartan, first, second and third order derivatization was carried out in Agilent Cary 60 UV/Vis double beam spectrophotometer. HPLC method was carried out by using Agilent 1220 Infinity LC equipped with Eclipse XDB plus C18 Column $(4.6 \times 150 \mathrm{~mm}, 5 \mu \mathrm{m})$ with a mobile phase consisting of a mixture Methanol and Acetonitrile in the ratio of 70:30 $\% \mathrm{v} / \mathrm{v}$ at a flow rate of $1 \mathrm{ml} / \mathrm{min}$. Results: The developed methods were validated as per $\mathrm{ICH}$ guidelines in terms of accuracy, precision, LOD and LOQ. The proposed methods were found to be suitable for simultaneous determination of Amlodipine Besylate and Valsartan in bulk and in pharmaceutical dosage forms. The results of the developed methods were then compared by student's t test. Conclusion: The developed methods were found to be simple, accurate, precise and rapid for simultaneous estimation of the selected drugs. The null hypothesis from student's t-test was found to be acceptable indicating no significant difference between the results of the proposed methods. Hence depending on the availability of instruments and reagents any of the proposed methods can effectively be applied for the routine analysis of Amlodipine besylate and Valsartan in bulk and in combined pharmaceutical dosage forms..
\end{abstract}

Key words: Amlodipine, Valsartan, Derivative Spectroscopy, RP-HPLC, T- test, Tablet.

\section{MAIN TEXT}

Amlodipine Besylate is a Calcium channel blocker used as an anti-hypertensive agent. Chemically it is 3-ethyl 5-methyl 2-[(2-aminoethoxy) methyl]-4-(2-chlorophenyl)-6-methyl-1, 4-Dihydropyridine-3.5-dicarboxylate. It is slightly soluble in water and sparingly soluble in ethanol. ${ }^{1}$
Valsartan is an angiotensin 11 receptor blocker used in the treatment of hypertension. Chemically itis(1S,3R,7S,8S,8aR)-8- $\{2-[(2 \mathrm{R}, 4 \mathrm{R})$ -4-hydroxy-6-oxooxan-2-yl] \}-3,7-dimethyl$1,2,3,7,8,8$ ahexahydronaphthalen-1-yl 2,2-dimethylbutanoate. ${ }^{2}$ It is soluble in methanol and ethanol and slightly soluble in
Submission Date: 31-03-2017; Revision Date: 15-06-2017; Accepted Date: 26-08-2017

DOI: 10.5530/ijper.51.4s.112 Correspondence:

Dr. N. Usharani, Vice principal, Maharajah's College of Pharmacy, Phool Baugh, Vizianagaram535002, Andhra Pradesh, INDIA.

Phone: 7382790583

E-mail: nusharani.au@gmail. com

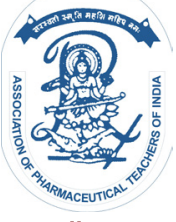

www.ijper.org 
water. The structure of Amlodipine and Valsartan are shown in the Figure 1 and 2.

\section{EXPERIMENTAL MATERIALS AND METHODS Instrument and Materials}

An Agilent Cary 60 UV-Visible double beam Spectrophotometer with $1 \mathrm{~cm}$ matched quartz cells was used for all spectral measurements. HPLC separation was carried out by Agilent prominence 1220 infinity LC equipped with Eclipse XDB plus C18 column. Pharmaceutical grade working standards of Amlodipine Besylate and Valsartan were obtained from Yarrow Chem Products. Fixed dosage combination tablet containing $10 \mathrm{mg}$ Amlodipine and $160 \mathrm{mg}$ Valsartan was purchased from local market Hyderabad, India. All the chemicals were of HPLC grade purchased from Fisher scientific and SD - fine chemicals, Mumbai. Milli-Q water was used.

\section{Analytical methods}

\section{UV Derivative spectroscopic method}

Working standard solutions containing $30 \mu \mathrm{g} / \mathrm{ml}$ of Amlodipine and Valsartan were scanned in the wavelength range of 200-400 nm using Methanol as reference in Agilent Cary $60 \mathrm{UV} / \mathrm{Vis}$ spectrophotometer (version 5. 0.0.999) in derivative mode and the corresponding overlain zero order spectrum was recorded which was converted to first (Figure 3), second (Figure 4) and third (Figure 5) order derivative spectra. Each spectrum was recorded in triplicate. ${ }^{3}$ For each replicate measurement the cell was refilled with fresh solution.

One particular wavelength was selected for each drug at which the absorbance of the other was found zero. From the examination of first, second and third order overlain derivative spectra, the working wavelengths were selected as $234.6 \mathrm{~nm}, 231.3 \mathrm{~nm} 239.6 \mathrm{~nm}$ for Amlodipine where Valsartan exhibited zero absorbance and $222.4 \mathrm{~nm}, 222.3 \mathrm{~nm} 232.9 \mathrm{~nm}$ for Valsartan where Amlodipine exhibited zero absorbance. The regression equations for the first, second and third order derivative spectra were obtained as $\mathrm{Y}=0.01 \mathrm{x}+0.002$, $Y=0.050 x+0.016, \quad Y=0.045 x+0.092$ for Amlodipine Besylate and $\mathrm{Y}=0.048 \mathrm{x}+0.038, \mathrm{Y}=0.04 \mathrm{x}+0.005$, $\mathrm{Y}=0.019 \mathrm{x}+0.027$ for Valsartan.

\section{RP-HPLC METHOD}

HPLC separation was carried out by Agilent prominence 1220 infinity LC equipped with Eclipse XDB plus C18 column using mobile phase consisting of Methanol and Acetonitrile in the ratio of $70: 30 \% \mathrm{v} / \mathrm{v}$ at a flow rate of $1 \mathrm{ml} / \mathrm{min}$. The sample injection volume was $20 \mu \mathrm{l}$ and the UV detection was carried out at $224.1 \mathrm{~nm}$ for the determination of both drugs. Figure 6 shows a typical chromatogram of Amlodipine Besylate and Valsartan. The retention times for Amlodipine Besylate and Valsartan were found to be $2.533 \mathrm{~min}$ and $1.083 \mathrm{~min}$ respectively. The calibration curves for the proposed drugs showed good linearity in the concentration range of $10-60 \mu \mathrm{g} / \mathrm{ml}^{4}$

\section{Procedure for the analysis of tablet formulation}

Twenty tablets (AMLOSARTAN) were weighed and made into a fine powder. The amount of powder equivalent to labeled claim of the drugs was taken in a volumetric flask. To it around $20 \mathrm{ml}$ of solvent (Methanol) was added and the flask was placed in an ultrasonic bath for $15 \mathrm{~min}$. The solution was then cooled and made up to volume with the same solvent. ${ }^{5}$ The solution was filtered through a $0.45 \mu \mathrm{m}$ filter and then the filtrate was used to prepare aliquots for UV-Derivative Spectroscopy and for RP-HPLC methods. The results were summarized as shown in Table 1. Figure 7 shows a typical chromatogram of Amlodipine Besylate and Valsartan in tablet solution.

\section{STATISTICAL METHOD OF ANALYSIS}

\section{Student's t-test}

The results obtained from UV- Derivative spectroscopic and RP-HPLC methods were subjected to student's t-test to assess the suitability of the methods in regular quality control of the selected drugs. The relevant test statistic, $t$, is calculated from the sample data and then compared with its probable value based on t-distribution at a specified level of significance for concerning degrees of freedom for accepting or rejecting the null hypothesis.

\section{RESULTS AND DISCUSSION}

Both UVDS and HPLC methods were validated according to International Conference on Harmonization guidelines for validation of analytical procedures. ${ }^{6}$

\section{Linearity}

The calibration curves constructed for both the drugs showed good linearity in the concentration range of $10-50 \mu \mathrm{g} / \mathrm{ml}$ for Amlodipine Besylate and Valsartan in UV Derivative Spectroscopic method and 10-60 $\mu \mathrm{g} / \mathrm{ml}$ for Amlodipine Besylate and Valsartan in HPLC method. The solutions were prepared in triplicate. The linearity was evaluated by linear regression analysis and the values were tabulated as shown in Table 2 .

\section{Accuracy}


<smiles>CCOC(=O)C1=C(COCCN)NC(C)=C(C(=O)OC)C1c1ccccc1Cl</smiles>

Amlodipine besylate

Figure 1: Structure of Amlodipine Besylate.<smiles>CCCCC(=O)N(Cc1ccc(-c2ccccc2-c2nnn[nH]2)cc1)[C@@H](C(=O)O)C(C)C</smiles>

Figure 2: Structure of Valsartan.

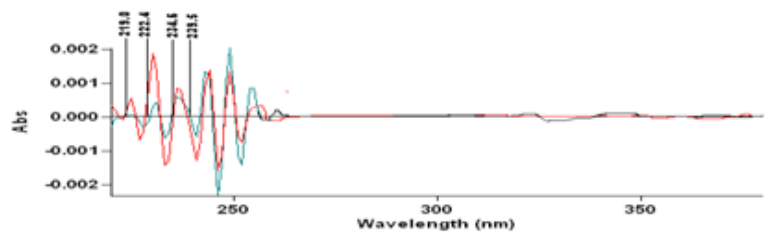

Figure 3: First order derivative spectrum of Amlodipine and Valsartan.

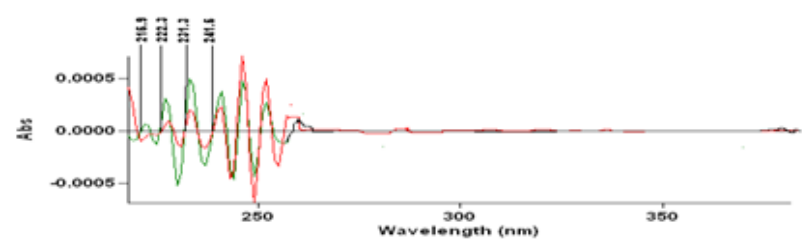

Figure 4: Second order derivative spectrum of Amlodipine and Valsartan.

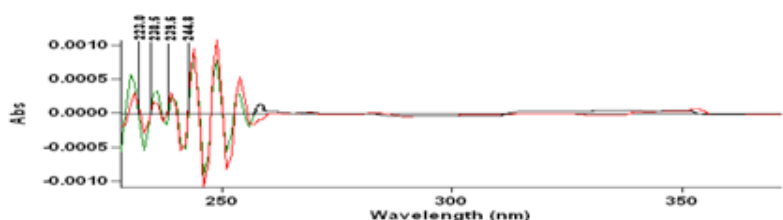

Figure 5: Third order derivative spectrum of Amlodipine and Valsartan.

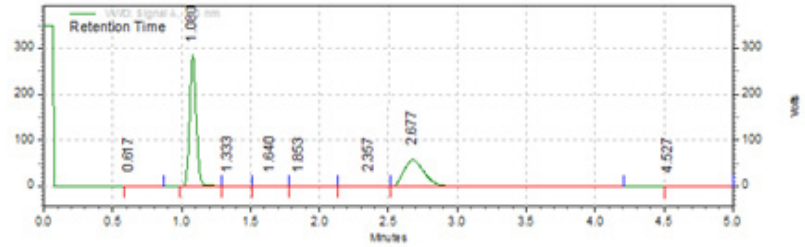

Figure 6: Chromatogram for Amlodipine besylate and Valsartan.

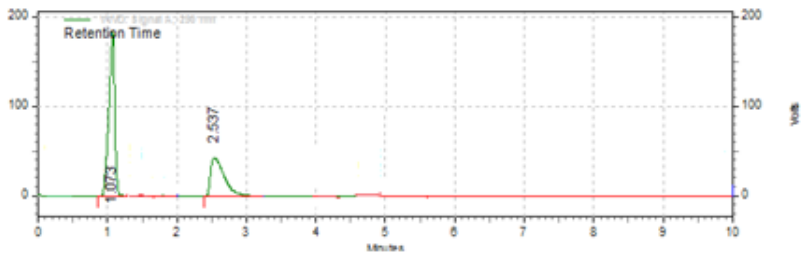

Figure 7: Chromatogram for tablet solution.

To check the accuracy of the proposed methods, recovery studies were carried out by applying standard addition method. A known amount of standard Amlodipine and Valsartan corresponding to 80,100 and $120 \%$ of the label claim was added to pre-analyzed sample of the tablet. ${ }^{7}$ The recovery studies were carried out in triplicate at each level and the results were summarized as shown in Table 3.

\section{Precision}

The precision of the assay was determined by repeatability (intra-day) and intermediate precision (inter-day) studies. ${ }^{8}$ Three sample solutions were prepared and analyzed. The results were summarized as shown in Table 4.

\section{Limit of detection and Limit of quantification}

LOD and LOQ for the proposed methods were calculated based on the standard deviation of the analytical response and the slope of the calibration curve using the equations $\mathrm{LOD}=3.3 \mathrm{\sigma} / \mathrm{S}$ and $\mathrm{LOQ}=10 \mathrm{\sigma} / \mathrm{S}$, 
Table 1: Analysis of marketed formulation.

\begin{tabular}{|c|c|c|c|c|c|c|}
\hline \multicolumn{2}{|c|}{ Formulation } & \multirow{2}{*}{$\begin{array}{c}\text { Amount present (mg) } \\
\text { Amount found (mg) }\end{array}$} & \multicolumn{2}{c|}{ UVDS method } & \multicolumn{2}{c|}{ HPLC method } \\
\cline { 4 - 7 } & & & \% Recovery & $\begin{array}{c}\text { Amount found } \\
\text { (mg) }\end{array}$ & \% Recovery \\
\hline \multirow{2}{*}{ AMLOSARTAN } & AML & 10 & 9.98 & 99.88 & 10.266 & 102.66 \\
\cline { 4 - 8 } & VAL & 160 & 159.96 & 99.77 & 159.88 & 99.93 \\
\hline
\end{tabular}

\begin{tabular}{|c|c|c|c|c|c|c|c|c|}
\hline \multirow{3}{*}{$\begin{array}{c}\text { Statistical } \\
\text { parameters }\end{array}$} & \multicolumn{6}{|c|}{ UV Derivative Spectroscopic method } & \multirow{2}{*}{\multicolumn{2}{|c|}{ HPLC method }} \\
\hline & \multicolumn{2}{|c|}{ First order } & \multicolumn{2}{|c|}{ Second order } & \multicolumn{2}{|c|}{ Third order } & & \\
\hline & Amlodipine & Valsartan & Amlodipine & Valsartan & Amlodipine & Valsartan & Amlodipine & Valsartan \\
\hline Linearity $(\mu \mathrm{g} / \mathrm{ml})$ & $10-50$ & $10-50$ & $10-50$ & $10-50$ & $10-50$ & $10-50$ & $10-60$ & $10-60$ \\
\hline $\begin{array}{c}\text { Correlation } \\
\text { coefficient }\left(\mathrm{R}^{2}\right)\end{array}$ & 0.997 & 0.997 & 0.999 & 0.998 & 0.998 & 0.997 & 0.998 & 0.998 \\
\hline $\begin{array}{c}\text { Regression } \\
\text { equation } y=m x+c\end{array}$ & $\begin{array}{c}Y=0.01 x+ \\
0.002\end{array}$ & $\begin{array}{c}Y=0.048 x+ \\
0.038\end{array}$ & $\begin{array}{c}Y=0.050+ \\
0.016\end{array}$ & $\begin{array}{c}Y=0.04+ \\
0.005\end{array}$ & $\begin{array}{c}Y=0.045 x+ \\
0.092\end{array}$ & $\begin{array}{c}Y=0.019 x+ \\
0.027\end{array}$ & $\begin{array}{c}Y=106.1 x+ \\
3147\end{array}$ & $\begin{array}{c}Y=9847 x+ \\
1613\end{array}$ \\
\hline Slope $(m)$ & 0.015 & 0.048 & 0.050 & 0.041 & 0.045 & 0.019 & 106.1 & 9847 \\
\hline Intercept(c) & 0.002 & 0.038 & 0.016 & 0.005 & 0.092 & 0.027 & 3147 & 1613 \\
\hline
\end{tabular}

where $\sigma$ is the $\mathrm{SD}$ of the response and $\mathrm{S}$ is the slope of calibration curve as shown in Table 5

\section{Ruggedness}

Ruggedness was determined by injecting the standard and sample solutions by two different analysts to check the reproducibility of the present analytical method. The results were summarized as shown in Table 6.

\section{Robustness}

Robustness of the developed analytical method was assessed by evaluating the affect of small variations in analytical method parameters such as change in flow rate from $1.2 \mathrm{ml} / \mathrm{min}$ by \pm 0.2 and change in wavelength by $\pm 2 \mathrm{~nm}$. The chromatograms were recorded and the results are shown in Table 7.

\section{Specificity}

The specificity of the proposed HPLC method was determined to check whether there is any interference due to presence of excipients, impurities or other components with the retention times of analytical peaks. ${ }^{9}$ Figure 8 shows the chromatogram indicating specificity of the method and the results were tabulated as shown in Table 8.

\section{System suitability}

Five replicates of working mixed standard solution were injected and the parameters like theoretical plate number $(\mathrm{N})$ and tailing factor $(\mathrm{K})$ were calculated to check the system suitability. ${ }^{10}$ Figure 9 shows the chromatogram for system suitability and the results were summarized as shown in Table 9.
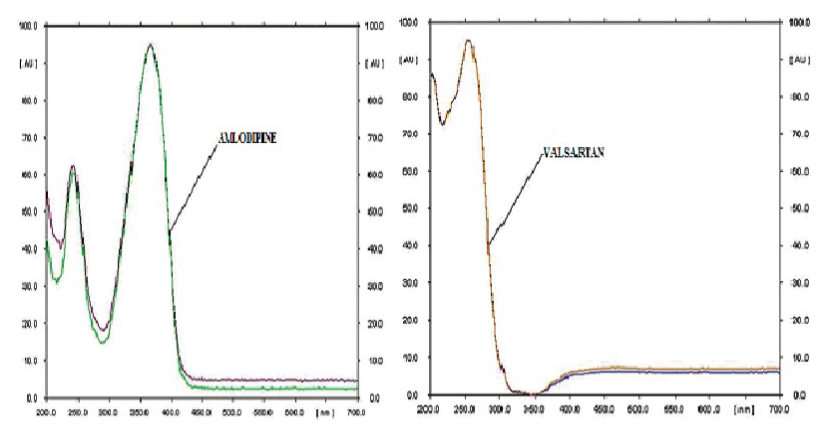

Figure 8: Peak purity spectra of Amlodipine and Valsartan.

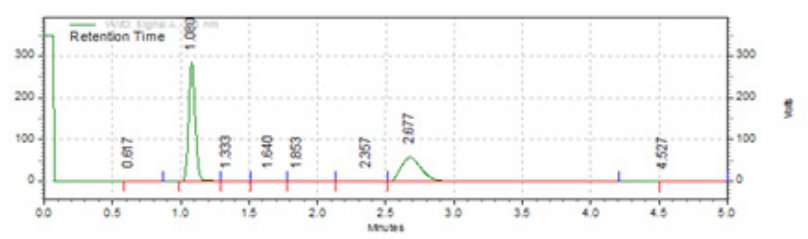

Figure 9: Chromatogram for System Suitability.

\section{Student's t-test}

The results obtained in the proposed methods were subjected to student's t-test to assess the suitability of the methods in regular quality control. The t-test results obtained were tabulated as shown in Table 10.

The $\mathrm{t}$-value for the $95 \%$ probability level $=2.365$, since the calculated values are less than the t-table values, the null hypothesis is correct and there is no significant difference between the proposed methods. 


\section{Table 3: Accuracy data of the proposed methods.}

\begin{tabular}{|c|c|c|c|c|c|}
\hline Method & $\begin{array}{l}\text { Amount of } \\
\text { tablet powder }\end{array}$ & $\begin{array}{l}\text { Amount of pure } \\
\text { drug added(mg) }\end{array}$ & $\begin{array}{l}\text { Amount } \\
\text { recovered } \\
\pm S D(n=3)\end{array}$ & $\%$ Recovery & $\%$ RSD \\
\hline \multicolumn{6}{|c|}{ Amlodipine besylate } \\
\hline UV & $10 \mathrm{mg}$ & $\begin{array}{c}8 \\
10 \\
12\end{array}$ & $\begin{array}{l}17.98 \pm 0.005 \\
19.98 \pm 0.005 \\
21.95 \pm 0.019\end{array}$ & $\begin{array}{l}99.88 \\
99.90 \\
99.77\end{array}$ & $\begin{array}{l}0.027 \\
0.025 \\
0.086\end{array}$ \\
\hline \multirow{2}{*}{ HPLC } & $40 \mu \mathrm{g} / \mathrm{ml}$ & $\begin{array}{l}32 \\
40 \\
48\end{array}$ & $\begin{array}{l}71.99 \\
79.98 \\
87.96\end{array}$ & $\begin{array}{l}99.95 \\
99.92 \\
99.94\end{array}$ & $\begin{array}{l}0.01 \\
0.06 \\
0.02\end{array}$ \\
\hline & $50 \mu \mathrm{g} / \mathrm{ml}$ & $\begin{array}{l}40 \\
50 \\
60 \\
\end{array}$ & $\begin{array}{c}89.99 \\
99.95 \\
109.95\end{array}$ & $\begin{array}{l}99.92 \\
99.95 \\
99.95 \\
\end{array}$ & $\begin{array}{l}0.04 \\
0.01 \\
0.09\end{array}$ \\
\hline \multicolumn{6}{|c|}{ Valsartan } \\
\hline UV & $160 \mathrm{mg}$ & $\begin{array}{l}128 \\
160 \\
192 \\
\end{array}$ & $\begin{array}{l}287.930 .02 \\
319.960 .02 \\
351.980 .03\end{array}$ & $\begin{array}{l}99.97 \\
99.98 \\
99.99\end{array}$ & $\begin{array}{l}0.0075 \\
0.0067 \\
0.0089\end{array}$ \\
\hline \multirow{2}{*}{ HPLC } & $20 \mu \mathrm{g} / \mathrm{ml}$ & $\begin{array}{l}16 \\
20 \\
24\end{array}$ & $\begin{array}{l}35.98 \\
39.98 \\
43.95\end{array}$ & $\begin{array}{l}99.91 \\
99.92 \\
99.98\end{array}$ & $\begin{array}{l}0.02 \\
0.05 \\
0.02\end{array}$ \\
\hline & $30 \mu \mathrm{g} / \mathrm{ml}$ & $\begin{array}{l}24 \\
30 \\
36\end{array}$ & $\begin{array}{l}53.96 \\
59.97 \\
63.97\end{array}$ & $\begin{array}{l}99.92 \\
99.91 \\
99.95\end{array}$ & $\begin{array}{l}0.01 \\
0.06 \\
0.01\end{array}$ \\
\hline
\end{tabular}

\begin{tabular}{|c|c|c|c|c|c|c|c|c|}
\hline \multirow{3}{*}{$\begin{array}{l}\text { Precision } \\
\text { parameters }\end{array}$} & \multicolumn{6}{|c|}{ UV Derivative Spectroscopic method } & \multirow{2}{*}{\multicolumn{2}{|c|}{ HPLC method }} \\
\hline & \multicolumn{2}{|c|}{ First order } & \multicolumn{2}{|c|}{ Second order } & \multicolumn{2}{|c|}{ Third order } & & \\
\hline & Amlodipine & Valsartan & Amlodipine & Valsartan & Amlodipine & Valsartan & Amlodipine & Valsartan \\
\hline \multirow{4}{*}{ Intra day } & 0.190 & 0.100 & 0.100 & 0.240 & 0.262 & 0.642 & \multirow{7}{*}{0.067} & \multirow{7}{*}{0.011} \\
\hline & 0.072 & 0.026 & 0.054 & 0.010 & 0.981 & 0.039 & & \\
\hline & 0.003 & 0.033 & 0.020 & 0.123 & 0.047 & 0.057 & & \\
\hline & & & & & & & & \\
\hline \multirow{3}{*}{ Inter day } & 0.100 & 0.201 & 0.112 & 0.518 & 0.482 & 0.148 & & \\
\hline & 0.007 & 0.026 & 0.078 & 0.780 & 0.228 & 0.054 & & \\
\hline & 0.017 & 0.033 & 0.247 & 0.050 & 0.013 & 0.036 & & \\
\hline
\end{tabular}

\begin{tabular}{|c|c|c|c|c|c|c|c|c|}
\hline \multirow{3}{*}{ Parameters } & \multicolumn{6}{|c|}{ UV Derivative Spectroscopic method } & \multirow{2}{*}{\multicolumn{2}{|c|}{ HPLC method }} \\
\hline & \multicolumn{2}{|c|}{ First order } & \multicolumn{2}{|c|}{ Second order } & \multicolumn{2}{|c|}{ Third order } & & \\
\hline & Amlodipine & Valsartan & Amlodipine & Valsartan & Amlodipine & Valsartan & Amlodipine & Valsartan \\
\hline $\mathrm{LOD} \mu \mathrm{g} / \mathrm{ml}$ & 0.044 & 0.261 & 0.105 & 0.402 & 0.674 & 0.468 & 0.97 & 0.54 \\
\hline $\mathrm{LOQ} \mu \mathrm{g} / \mathrm{ml}$ & 0.133 & 0.7916 & 0.320 & 0.1219 & 2.044 & 1.421 & 0.29 & 1.63 \\
\hline
\end{tabular}

\begin{tabular}{|c|c|c|c|}
\hline \multicolumn{5}{|c|}{ Table 6: Ruggedness for proposed method. } \\
\hline S.NO & Parameters & Amlodipine & Valsartan \\
\hline \multicolumn{4}{|c|}{ UV Derivative Spectroscopic method } \\
\hline 1 & Analyst-01 & $102.33 \% \mathrm{w} / \mathrm{w}$ & $99.94 \% \mathrm{w} / \mathrm{w}$ \\
\hline 2 & Analyst-02 & $99.98 \% \mathrm{w} / \mathrm{w}$ & $99.82 \% \mathrm{w} / \mathrm{w}$ \\
\hline \multicolumn{4}{|c|}{ HPLC method } \\
\hline 1 & Analyst-01 & $100.21 \% \mathrm{w} / \mathrm{w}$ & $101.43 \% \mathrm{w} / \mathrm{w}$ \\
\hline 2 & Analyst-02 & $99.97 \% \mathrm{w} / \mathrm{w}$ & $99.72 \% \mathrm{w} / \mathrm{w}$ \\
\hline
\end{tabular}




\begin{tabular}{|c|c|c|c|c|c|c|c|}
\hline \multirow{3}{*}{ S. No } & \multirow{3}{*}{ Parameters } & \multicolumn{3}{|c|}{ Amlodipine Besylate } & \multicolumn{3}{|c|}{ Valsartan } \\
\hline & & \multicolumn{6}{|c|}{ HPLC method } \\
\hline & & $\begin{array}{l}\text { Retention } \\
\text { time (min) }\end{array}$ & $\begin{array}{l}\text { Peak area } \\
\left(\mathrm{mV}^{*} \min \right)\end{array}$ & $\begin{array}{l}\text { Tailing } \\
\text { factor }\end{array}$ & $\begin{array}{l}\text { Retention } \\
\text { time (min) }\end{array}$ & $\begin{array}{l}\text { Peak area } \\
\left(\mathrm{mV}^{*} \min \right)\end{array}$ & $\begin{array}{l}\text { Tailing } \\
\text { factor }\end{array}$ \\
\hline 1 & Standard & 2.677 & 16102.21 & 1.37 & 1.080 & 2812.58 & 1.16 \\
\hline 2 & Flow rate $(0.5 \mathrm{ml} / \mathrm{min})$ & 2.521 & 16121.01 & 1.42 & 1.075 & 2814.59 & 1.34 \\
\hline 3 & Flow rate $(0.8 \mathrm{ml} / \mathrm{min})$ & 2.512 & 16011.24 & 1.38 & 1.068 & 2812.51 & 1.25 \\
\hline 4 & Mobile phase $(50: 50 \% \mathrm{v} / \mathrm{v})$ & 2.514 & 16124.26 & 1.52 & 1.059 & 2810.25 & 1.50 \\
\hline 5 & Mobile phase $(80: 20 \mathrm{v} / \mathrm{v})$ & 2.516 & 16012.50 & 1.40 & 1.086 & 2813.38 & 1.32 \\
\hline 6 & Wavelength (230) & 2.511 & 16102.24 & 1.48 & 1.067 & 2807.45 & 1.46 \\
\hline \multirow[t]{3}{*}{7} & Wavelength (245) & 2.516 & 16104.12 & 1.46 & 1.053 & 2805.27 & 1.10 \\
\hline & & \multicolumn{6}{|c|}{ UV Derivative Spectroscopic method } \\
\hline & & \multicolumn{3}{|c|}{$\%$ Recovery for Amlodipine } & \multicolumn{3}{|c|}{$\%$ Recovery for Valsartan } \\
\hline 1 & Wavelength(230) & \multicolumn{3}{|c|}{101.88} & \multicolumn{3}{|c|}{101.77} \\
\hline 2 & Wavelength (245) & \multicolumn{3}{|c|}{99.82} & \multicolumn{3}{|c|}{99.86} \\
\hline
\end{tabular}

\begin{tabular}{|c|c|c|c|c|}
\hline \multicolumn{5}{|c|}{ Table 8: Specificity of the proposed method. } \\
\hline \multirow{2}{*}{ Sample } & \multicolumn{2}{|c|}{ Peak Area mV*min } & \multicolumn{2}{c|}{$\%$ Content of Drug } \\
\cline { 2 - 5 } & Amlodipine & Valsartan & Amlodipine & Valsartan \\
\hline Standard & 4995.64 & 3996.30 & 99.28 & 99.90 \\
\hline Standard+Placebo & 4997.97 & 3998.29 & 99.95 & 99.95 \\
\hline Placebo & 0 & 0 & 0 & 0 \\
\hline
\end{tabular}

\begin{tabular}{|c|c|c|}
\hline \multicolumn{2}{|c|}{ Table 9: System suitability of the proposed } \\
method. \\
\hline \multirow{2}{*}{ System suitability parameters } & \multicolumn{2}{|c|}{ Results } \\
\cline { 2 - 3 } & Amlodipine & Valsartan \\
\hline Tailing Factor & 1.37 & 1.16 \\
\hline Number of theoretical plates & 5110 & 3882 \\
\hline
\end{tabular}

\section{CONCLUSION}

The developed UV- derivative spectroscopic and RPHPLC methods were found to be simple, accurate, precise and rapid for determination of Amlodipine and Valsartan in combined dosage form. The proposed UV- derivative Spectroscopic methods exploit the zero crossing technique for obtaining the first, second and third order derivative spectra indicating the simplicity of the method. The methods were found to be economical. The methods were developed and validated for various parameters as per ICH guidelines. The results obtained were within the acceptance criteria. The proposed methods were compared using student's t-test. Since the calculated t- values were found to be less than the t-table values, the null hypothesis is correct and

\begin{tabular}{|c|c|c|}
\hline \multicolumn{2}{|c|}{ Table 10: Application of Student's t-test for the } \\
proposed methods \\
\hline \multirow{2}{*}{ Student's t-test } & \multicolumn{2}{|c|}{ t-value } \\
\cline { 2 - 3 } & Amlodipine & Valsartan \\
\hline First order UVDS and HPLC & 0.094 & 1.243 \\
\hline Second order UVDS and HPLC & 0.906 & 0.90 \\
\hline Third order UVDS and HPLC & 0.630 & 1.310 \\
\hline
\end{tabular}

there is no significant difference between the proposed methods. Hence, the proposed methods were found to be satisfactory and any of these two methods could be used for the routine analysis of Amlodipine Besylate and Valsartan in combined dosage form basing on the availability of instrument and reagents.

\section{ACKNOWLEDGEMENT}

The authors are thankful to Yarrow Chem Products, Fisher scientific and SD - fine chemicals, Mumbai for providing all the chemicals required for the investigation. The authors also acknowledge the laboratory facilities provided by Maharajah's College of Pharmacy, Vizianagaram, and Andhra Pradesh, India for this study. 


\section{CONFLICT OF INTEREST}

There are no conflict of interest.

\section{ABBREVIATION USED}

UVDS: UV Derivative Spectroscopy; HPLC: High Performance Liquid Chromatography; ICH: International Council for Harmonization.

\section{REFERENCES}

1. Arthur Israel Vogel. Vogel's textbook of quantitative inorganic analysis. $4^{\text {th }}$ ed. New York: Longman Publisher; 1978.1-12.

2. Willard HH, Merritt LL, Dean JA, Settle FA. Instrumental methods of analysis. $6^{\text {th }}$ ed. New Delhi: CBS publishers and distributors. 1986;1-15.

3. Lindsay S. High Performance Liquid Chromatography. $1^{\text {st }}$ ed. London: John Wiley and Sons; 1991. 45- 75.

4. Snyder LR, Kirkland JJ, Joseph LG. Practical HPLC method development. $2^{\text {nd }}$ ed. New York: Wiley and sons; 1997.
5. Chitlange SS, Kiran B, Wankhede SB, Sakarkar DN. Simultaneous Spectrophotometric estimation of Amlodipine and Valsartan in capsule formulation. Oriental Journal of Chemistry. 2008;24(2):689-92.

6. Gupta KR, Mahapatra AD, Wadodkar AD, Wadodkar SG. Simultaneous UV spectrophotometric determination of Valsartan and Amlodipine in tablet. International Journal of Chemistry Technology Research. 2010;2:555-6.

7. Varsha R, Galande K, Baheti G, Indraksha S. Estimation of Amlodipin besylate, Valsartan and Hydrochlorothiazide in bulk mixture and tablet. Indian Journal of Pharmaceutical Science. 2010;74(1):18-23.

8. Grishma ST, Hasumati ARK, Vineet CJ. First derivative spectroscopic method for simultaneous estimation of Pravstatin and Valsartan in synthetic mixture. Asian Journal of Pharmaceutical Technology. 2015;5(2):83-90.

9. Rahul N, Ramesh S. Stability indicating RP-HPLC method for simultaneous estimation of Amlodipine Besylate and Valsartan combination in bulk and commercial dosage forms. Asian Journal of Pharmacy and Life Sciences. 2012;2(2):20-3.

10. Snehal PB, Bharat CG, Munish BK, Ashok PB. Stability indicating RPHPLC method for simultaneous determination of Valsartan and Amlodipine from their combination drug product. International Journal of Chem Tech Research. 2009;1(4):1257-67.

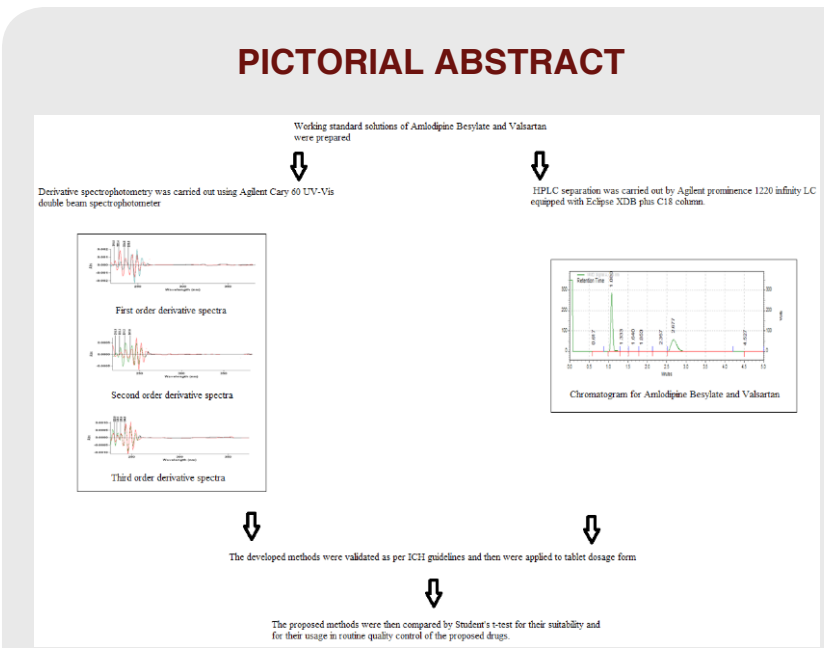

About Authors

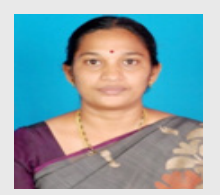

Dr. N. Usharani, M. Pharm, Ph. D, Vice- Principal, Maharajah's College of Pharmacy, Phool Baugh, Vizianagaram.

Divya K, M. Pharmacy, Maharajah's College of Pharmacy, Phool Baugh, Vizianagaram.

Ashrtiha VVS, M. Pharmacy, Maharajah's College of Pharmacy, Phool Baugh, Vizianagaram.

\section{SUMMARY}

- A UV derivative spectrophotometric method and high-performance liquid chromatographic method for the simultaneous determination of Amlodipine Besylate and Valsartan in tablets were developed in the present work. First, second and third order derivatization was carried out in Agilent Cary $60 \mathrm{UV} / \mathrm{V}$ is double beam spectrophotometer. HPLC method was carried out by using Agilent 1220 Infinity LC equipped with Eclipse XDB plus C18 Column (4.6 × 150 mm, $5 \mu \mathrm{m})$ with a mobile phase consisting of Methanol and Acetonitrile in the ratio of $70: 30 \% \mathrm{v} / \mathrm{v}$ at a flow rate of $1 \mathrm{ml} / \mathrm{min}$. Both the drugs showed linearity within the range of $10-50 \mu \mathrm{g} / \mathrm{ml}$ for UVDS and $10-60 \mu \mathrm{g} / \mathrm{ml}$ for HPLC method. The results obtained for validation studies were within the acceptance range as per ICH guidelines indicating the methods to be quite accurate, precise and sensitive. Both the methods were compared by Student's t-test, where it was found that the proposed methods can be used for the routine analysis of Amlodipine Besylate and Valsartan in combined dosage forms.

Cite this article: Usharani. Development and Validation of UV-Derivative Spectroscopic and RP-HPLC Methods for the Determination of Amlodipine Besylate and Valsartan in Tablet Dosage form and Comparison of the Developed Methods by Student's T-Test. Indian J of Pharmaceutical Education and Research. 2017;51(4S):S776-S82. 